\title{
Tigecycline Treatment of Urinary Tract Infection and Prostatitis: Case Report and Literature Review
}

\author{
Duane Bates, Mike Parkins, Robin Hellweg, Kimberly Gibson, and Jennifer M Bugar
}

\section{INTRODUCTION}

T igecycline, the first glycycline antibiotic, has been available in Canada since 2007. A systematic review of 8 randomized controlled trials (with a total of 4651 patients) ${ }^{1}$ suggested that the clinical and microbiological outcomes of tigecycline monotherapy were similar to those of empiric antibiotic regimens in the treatment of complicated skin and skin structure infections, intra-abdominal infections, and community-acquired pneumonia and other infections caused by methicillin-resistant Staphylococcus aureus (MRSA) or vancomycin-resistant Enterococcus (VRE). However, the incidence of adverse events, particularly nausea, was significantly higher with tigecycline than with the comparators. ${ }^{1}$ In September 2010, the US Food and Drug Administration issued a safety communication suggesting an increased risk of death with tigecycline relative to other antibiotics used to treat similar infections. ${ }^{2}$ The risk was greatest for patients with hospital-acquired pneumonia, especially ventilator-associated pneumonia. The clinical use of tigecycline therapy is generally reserved for treatment of multidrug-resistant (MDR) organisms. There are very limited data regarding its use in the treatment of urinary tract infections, as urinary excretion is a minor route of elimination for this drug. Even with no clinical trials, the drug has been suggested as an alternative for the treatment of complicated and nosocomial or catheter-related urinary tract infections caused by MDR Enterobacteriaceae, Acinetobacter baumannii, and VRE. ${ }^{3}$

We report a case of persistent urinary tract infection secondary to prostatitis that was treated with tigecycline and review the literature concerning use of this drug for treatment of urinary tract infections.

\section{CASE REPORT}

An 86-year-old man was admitted to hospital with acute onset of left-sided lower-quadrant pain radiating to the flank, accompanied by nausea, fever, chills, and rigors. The medical history included chronic kidney disease (baseline serum creatinine 200-250 $\mu \mathrm{mol} / \mathrm{L}$ ), diabetes mellitus, hypertension, and benign prostatic hypertrophy. The patient had returned from a 4-month trip to India 4 days before admission. He had been admitted to hospital twice while in India for pyelonephritis, but no information regarding his course in hospital, medications, or other treatment modalities could be obtained. Medications preceding admission included short- and longacting insulin (30/70) twice daily, amlodipine $5 \mathrm{mg}$ daily, tamsulosin $0.4 \mathrm{mg}$ daily, pantoprazole $40 \mathrm{mg}$ daily, lorazepam $1 \mathrm{mg}$ at bedtime as needed, cetirizine $10 \mathrm{mg}$ daily, and acetaminophen as needed. The patient had no known drug allergies and weighed $58.2 \mathrm{~kg}$ at the time of admission.

On physical examination, the patient was alert and oriented to person, place, and time. The results of neurological, head and neck, respiratory, and cardiovascular examinations were unremarkable. Abdominal examination revealed distension of the abdomen, with pain and tenderness in the left lower and upper quadrants radiating to the left flank. Musculoskeletal examination revealed a nonblanchable rash on the arms and legs, but no further description of the rash was documented. The patient was hemodynamically stable and afebrile.

At the time of admission, serum creatinine was $301 \mu \mathrm{mol} / \mathrm{L}$ (normal range 50-120 $\mu \mathrm{mol} / \mathrm{L}$ ), with an estimated creatinine clearance of $13 \mathrm{~mL} / \mathrm{min}$ (Cockcroft-Gault formula). Other laboratory measurements were serum potassium $5.2 \mathrm{mmol} / \mathrm{L}$ (normal range 3.3-5.1 mmol/L), carbon dioxide $19 \mathrm{mmol} / \mathrm{L}$ (normal range $21-31 \mathrm{mmol} / \mathrm{L}$ ), serum lactate $2.4 \mathrm{mmol} / \mathrm{L}$ (normal range $\leq 2 \mathrm{mmol} / \mathrm{L}$ ), and serum glucose $11.3 \mathrm{mmol} / \mathrm{L}$ (normal range 3.6-11.1 mmol/L). All other electrolytes and the results of liver function tests were within normal ranges. Coagulation parameters were slightly elevated, with an international normalized ratio of 1.3 (normal range 0.9-1.1) and partial thromboplastin time of $35.8 \mathrm{~s}$ (normal range 25-35 s). Complete blood count revealed hemoglobin $110 \mathrm{~g} / \mathrm{L}$ 
(normal range 137-180 g/L), platelets $180 \times 10^{9} / \mathrm{L}$ (normal range $150 \times 10^{9} / \mathrm{L}$ to $400 \times 10^{\%} / \mathrm{L}$ ), white blood cell count $27 \times 10^{9} / \mathrm{L}$ (normal range $4 \times 10^{9} / \mathrm{L}$ to $11 \times 10^{9} / \mathrm{L}$ ), and neutrophils $24 \times 10^{9} / \mathrm{L}$ (normal range $2 \times 10^{9} / \mathrm{L}$ to $8 \times 10^{9} / \mathrm{L}$ ).

Urinalysis showed a large amount of blood and leukocytes. In addition, the urine was nitrite-positive, with $1 \mathrm{~g} / \mathrm{L}$ protein, and the microscopic field was obscured by white blood cells. Electrolytes in the urine were normal. Computed tomography (CT) of the abdomen and pelvis revealed mild hydronephrosis, hydroureter of the left kidney, and asymmetric soft-tissue thickening near the left ureterovesical junction, which suggested a possible obstructing mass. Obstructive urosepsis was diagnosed, and samples of urine and blood were drawn for culture. The patient was given empiric therapy consisting of 1 dose of ceftriaxone $2 \mathrm{~g} \mathrm{IV}$, followed by piperacillin-tazobactam $2.25 \mathrm{~g}$ IV q8h, and a nephrostomy tube was placed by ultrasound guidance. The preliminary urine culture report suggested more than $1 \times 10^{8}$ colony-forming units $(\mathrm{cfu}) / \mathrm{L}$ of gram-negative bacilli. Gram staining of the blood culture revealed gramnegative bacilli resembling coliform bacteria. Nasal and rectal swabs were negative for MRSA, but the rectal swab was positive for vancomycin-resistant Enterococcus faecium.

On day 2, cultured samples of urine and blood grew Escherichia coli (see Table 1). Infectious diseases specialists were consulted. The piperacillin-tazobactam was discontinued, and meropenem $500 \mathrm{mg}$ IV twice daily for 14 days was initiated, given the perceived risk of an extended-spectrum ß-lactamase (ESBL) organism associated with travel to the Indian subcontinent. The microbiology department confirmed that the bacterium was not a New Delhi metallo-B-lactamase-1 isolate.

On day 3, the meropenem was discontinued to reduce Pseudomonas-selective pressure. Antibiotic therapy was changed to renally adjusted ertapenem $500 \mathrm{mg}$ IV daily for 14 days. The
E. coli specimens isolated from the urine and blood were subsequently determined to produce ESBL but not AmpC cephalosporinase (Table 1). By this time, the patient's flank pain had resolved.

On day 4, a painful, pruritic erythematous macular rash developed on the patient's palms, arms, thighs, ankles, and feet. The rash was nonpalpable and nonblanchable, and a possible connection with carbapenem therapy was considered. Given the convincing presentation, a dermatology specialist was not consulted, nor was a skin sample taken for biopsy. The therapeutic options were limited, so ertapenem was changed to tigecycline $100 \mathrm{mg}$ IV once, followed by $50 \mathrm{mg}$ IV twice daily. Magnetic resonance imaging of the pelvis showed thickening of the bladder suggesting chronic obstruction of the bladder outlet, mild enlargement of the prostate, no mass of the pelvis or ureterovesical junction, and normal ureters. On day 6, the nephrostomy tube was removed, and by day 9 the rash had resolved.

On day 15, while continuing to receive tigecycline therapy, the patient had slightly elevated counts of white blood cells $\left(11.2 \times 10^{\%} / \mathrm{L}\right)$ and neutrophils $\left(10 \times 10^{\%} / \mathrm{L}\right)$ but was afebrile. There was no documentation of dysuria, urgency, or increased urinary frequency. Urinalysis and microscopy revealed that the urine was nitrite-negative, with moderate quantities of leukocytes and bacteria, white blood cells above 30 per high-power field (normal range $0-5$ per high-power field), and the presence of yeast. The patient received a single oral dose of fluconazole $100 \mathrm{mg}$. Culture of the urine yielded more than $1 \times 10^{8} \mathrm{cfu} / \mathrm{L}$ of ESBL-producing $E$. coli (Table 1). The blood culture results were negative. Given the presence of persistent bacteriuria, a diagnosis of chronic prostatitis was considered, for which the duration of antibiotic treatment would be 6 weeks. Tigecycline $50 \mathrm{mg}$ IV twice daily was

\section{Table 1. Summary of Results of Sensitivity Testing of Escherichia coli* Cultured from Urine and Bloodt}

\begin{tabular}{|c|c|c|c|c|c|c|}
\hline \multirow[b]{2}{*}{ Drug } & \multicolumn{5}{|c|}{ Urine Culture } & \multirow{2}{*}{$\frac{\text { Blood Culture }}{\text { Day } 2^{*}}$} \\
\hline & Day 2 & Day 15 & Day 29 & Day 46 & Day 88 & \\
\hline Amoxicillin-clavulanate & $\mathrm{S}$ & $\mathrm{S}$ & $\mathrm{S}$ & $\mathrm{S}$ & $\mathrm{S}$ & \\
\hline Ampicillin & $\mathrm{R}$ & $\mathrm{R}$ & $\mathrm{R}$ & $\mathrm{R}$ & $\mathrm{R}$ & $\mathrm{R}$ \\
\hline Cefazolin & $\mathrm{R}$ & $\mathrm{R}$ & $\mathrm{R}$ & $\mathrm{R}$ & $\mathrm{R}$ & $\mathrm{R}$ \\
\hline Cefepime & $\mathrm{R}$ & $\mathrm{R}$ & $\mathrm{R}$ & $\mathrm{R}$ & $\mathrm{R}$ & $\mathrm{R}$ \\
\hline Ceftriaxone & $\mathrm{R}$ & $\mathrm{R}$ & $\mathrm{R}$ & $\mathrm{R}$ & $\mathrm{R}$ & $\mathrm{R}$ \\
\hline Cephalothin & $\mathrm{R}$ & $\mathrm{R}$ & $\mathrm{R}$ & $\mathrm{R}$ & $\mathrm{R}$ & \\
\hline Ciprofloxacin & $\mathrm{R}$ & $\mathrm{R}$ & $\mathrm{R}$ & $\mathrm{R}$ & $\mathrm{R}$ & $\mathrm{R}$ \\
\hline Ertapenem & $\mathrm{s}$ & & & & & \\
\hline Gentamicin & $\mathrm{s}$ & $\mathrm{s}$ & $\mathrm{s}$ & $\mathrm{s}$ & $\mathrm{s}$ & $\mathrm{s}$ \\
\hline Meropenem & $\mathrm{s}$ & $\mathrm{s}$ & $\mathrm{s}$ & $\mathrm{s}$ & $\mathrm{s}$ & $\mathrm{s}$ \\
\hline Nitrofurantoin & $\mathrm{s}$ & $\mathrm{s}$ & $\mathrm{s}$ & $\mathrm{s}$ & $\mathrm{s}$ & \\
\hline Sulfamethoxazole-trimethoprim & $\mathrm{s}$ & $\mathrm{s}$ & $\mathrm{s}$ & & $\mathrm{s}$ & $\mathrm{s}$ \\
\hline Tigecycline & & & $\mathrm{s}$ & & & \\
\hline Tobramycin & & & & $\mathrm{s}$ & & \\
\hline
\end{tabular}

$\mathrm{R}=$ resistant, $\mathrm{S}=$ sensitive.

*Extended-spectrum B-lactamase-producing Escherichia coli was cultured from urine (all dates) and blood.

tWhere neither $\mathrm{R}$ nor $\mathrm{S}$ is indicated for a particular drug on a particular date, testing was not performed. 
continued, and a urology specialist was consulted to discuss potential cystoscopy.

On day 17 , ultrasonography of the abdomen showed echogenic renal parenchyma consistent with changes associated with renal disease. The left side demonstrated fullness of the intrarenal collecting system without gross hydronephrosis, and on the right side there were multiple, apparently simple renal cortical cysts. On day 25 the patient underwent cystoscopy with fluoroscopy, which showed a normal bladder but a persistent filling defect in the left ureter at the mid-distal region. On day 26, repeat CT of the abdomen and pelvis suggested no evidence of left ureteric obstruction. A decrease in the nephromegaly and inflammation surrounding the left kidney suggested resolution of the left-sided pyelonephritis and pyelitis with no evidence of abscess. On day 27, the patient underwent left ureteroscopy, which did not suggest the presence of any pathologic condition.

On day 29, the tigecycline was discontinued. Repeat urinalysis and microscopy showed that the urine was nitritenegative, with a large quantity of leukocytes, few bacteria, and 6-10 white blood cells per high-power field. Culture of the urine yielded $1 \times 10^{7}$ to $1 \times 10^{8} \mathrm{cfu} / \mathrm{L}$ of ESBL-producing E. coli. The microbiology department confirmed that the bacteria were susceptible to tigecycline (Table 1). On day 32, infectious diseases specialists were consulted again because of the persistent bacteriuria. Repeat abdominal ultrasonography did not suggest any renal obstruction or hydronephrosis. Urinary postvoid residual volume was $6 \mathrm{~mL}$ (normal range less than $50 \mathrm{~mL}$ ). The patient did not have any symptoms of a urinary tract infection or prostatitis. Therefore, no further treatment was recommended, and on day 33 the patient was discharged to home, at which time serum creatinine was $239 \mu \mathrm{mol} / \mathrm{L}$

On day 46 , the patient returned to the emergency department with right flank pain but no urinary tract symptoms. Pertinent findings of a physical examination included rightsided tenderness of the costovertebral angle. Vital signs were blood pressure $165 / 88 \mathrm{~mm} \mathrm{Hg}$, heart rate 90/min, oxygen saturation $100 \%$ on room air, respiratory rate $20 / \mathrm{min}$, and temperature $38^{\circ} \mathrm{C}$. Hemoglobin was $99 \mathrm{~g} / \mathrm{L}$, platelets $175 \times 10^{\%} / \mathrm{L}$, white blood cells $13.1 \times 10^{9} / \mathrm{L}$, neutrophils $11.4 \times 10^{9} / \mathrm{L}$, serum potassium $5.2 \mathrm{mmol} / \mathrm{L}$, carbon dioxide $19 \mathrm{mmol} / \mathrm{L}$, blood glucose $11.8 \mathrm{mmol} / \mathrm{L}$, and serum creatinine $264 \mu \mathrm{mol} / \mathrm{L}$.

Urinalysis and microscopy revealed that the urine was nitrite-negative, with a large number of leukocytes, protein $0.3 \mathrm{~g} / \mathrm{L}$, a moderate amount of blood, and more than 30 white blood cells per high-power field. Culture of the urine yielded more than $1 \times 10^{8} \mathrm{cfu} / \mathrm{L}$ of ESBL-producing $E$. coli (Table 1 ). The blood culture results were negative. Abdominal ultrasonography revealed several small homogenous cortical cysts in both kidneys. No hydronephrosis or renal calculi were seen, nor was there evidence of urinary tract obstruction.

Upon consultation, the infectious diseases specialist thought that the most likely source of the bacteriuria was the prostate. The recommendation was to give tigecycline $100 \mathrm{mg}$ IV once, followed by $50 \mathrm{mg}$ twice daily for 6 weeks. The patient tolerated both courses of tigecycline and did not report any nausea; the results of all liver function tests remained within normal ranges. On day 88 , the tigecycline was discontinued. The patient did not report any urinary tract symptoms, did not have any difficulty voiding, and was discharged to home.

On day 152, the patient was readmitted to hospital with shortness of breath secondary to heart failure. Vital signs were blood pressure 155/62 $\mathrm{mm} \mathrm{Hg}$, heart rate 69/min, oxygen saturation $98 \%$ on room air, and respiratory rate $14 / \mathrm{min}$, and the patient was afebrile. Hemoglobin was $111 \mathrm{~g} / \mathrm{L}$, platelets $99 \times 10^{\%} / \mathrm{L}$, white blood cells $16.6 \times 10^{9} / \mathrm{L}$, neutrophils $15.5 \times 10^{9} / \mathrm{L}$, serum potassium $6.8 \mathrm{mmol} / \mathrm{L}$, carbon dioxide $11 \mathrm{mmol} / \mathrm{L}$, blood glucose $36.7 \mathrm{mmol} / \mathrm{L}$, and serum creatinine $298 \mu \mathrm{mol} / \mathrm{L}$.

Urinalysis and microscopy revealed that the urine was nitrite-negative, with a small quantity of leukocytes, no protein, a moderate amount of blood, and more than 30 white blood cells per high-power field. Culture of the urine yielded more than $1 \times 10^{8} \mathrm{cfu} / \mathrm{L}$ of ESBL-producing E. coli (Table 1). Sensitivity to tigecycline was not reported. The blood culture results were negative. A digital rectal examination showed no evidence of prostatitis. Given the patient's recent history, empiric therapy with tigecycline was started: one dose of $100 \mathrm{mg}$ IV, followed by $50 \mathrm{mg}$ IV twice daily. However, on day 157 , the tigecycline was stopped, both because the patient had not had any symptoms of a urinary tract infection at the time of admission and because colonization with ESBL-producing E. coli was thought to be likely.

\section{DISCUSSION}

Tigecycline is one of the few antibiotics with in vitro activity against MDR Klebsiella pneumoniae and $A$. baumannii. However, clinical data regarding its effectiveness against infections caused by ESBL-producing bacteria are rare. ${ }^{4,5}$ Some clinicians have debated the use of tigecycline for treatment of urinary tract infection caused by MDR bacteria, on the basis of concerns about inadequate drug concentrations in the urine. A brief overview of the pharmacokinetics and pharmacodynamics of tigecycline is necessary to evaluate the use of this drug in urinary tract infection and prostatitis.

Tigecycline has a volume of distribution of $7-10 \mathrm{~L} / \mathrm{kg}$, which is much greater than most other classes of antimicrobials. ${ }^{6}$ In vitro, the drug is approximately $71 \%-89 \%$ bound to plasma proteins. Various studies have suggested that the drug distributes into bile; the epithelial lining; synovial, skin blister, 
ascitic, and cerebrospinal fluids; polymorphonuclear cells; and tissues such as the colon, lung, and bone. ${ }^{6-8}$ Pfizer Canada did not have any information on penetration of tigecycline into the prostate (J. Drummond, Medical Information, Pfizer Canada; personal communication, August 5, 2011). However, minocycline, from which tigecycline is derived, is regarded as having good prostatic penetration. More specifically, penetration of minocycline into the prostatic tissue achieves levels $40 \%-100 \%$ of the corresponding serum concentrations. ${ }^{910}$ Tigecycline is not extensively metabolized. The 2 major metabolic pathways are glucuronidation and amide hydrolysis to metabolites with negligible pharmacological activity. ${ }^{8}$ The major route of elimination is biliary and fecal excretion (59\%). ${ }^{6,7}$ An additional 33\% undergoes renal excretion, with only $10 \%-15 \%$ of the total dose being excreted as unchanged drug. ${ }^{6}$ After multiple doses, the half-life of tigecycline is approximately $42 \mathrm{~h}$.

Tigecycline inhibits protein synthesis at the level of the bacterial ribosome by blocking the binding of amino-acyl tRNA to the A site of the ribosome. ${ }^{7,8}$ Similar to the tetracyclines, tigecycline generally exhibits a bacteriostatic pattern of antimicrobial activity. However, its activity depends on the pathogen and strain examined, as well as the methods and exact definitions used, as bactericidal activity against Streptococcus pneumoniae has been demonstrated. ${ }^{8}$ Given the prolonged post-antibiotic effect against most pathogens (approximately 1-4.5 h), along with the extensive volume of distribution and prolonged elimination half-life, the ratio of area under the curve to minimum inhibitory concentration (AUC/MIC ratio) has been proposed as the most important pharmacodynamic index of tigecycline. ${ }^{6,8}$

A systematic review of the literature was conducted to identify publications describing the use of tigecycline in the treatment of urinary tract infection or prostatitis. The search terms "tigecycline", "urinary tract infection", "pyelonephritis", and "prostatitis" were used to search PubMed (January 1948 to December 2011), Ovid (January 1948 to December 2011), Embase (January 1974 to December 2011), and International Pharmaceutical Abstracts (January 1970 to December 2011). A total of 13 cases and 1 case series (which had just one patient with a urinary tract infection) were identified. ${ }^{11-19}$ One of these cases was excluded from the analysis because insufficient information was reported. ${ }^{11}$

The remaining 12 cases of tigecycline therapy for urinary tract infection or prostatitis were reviewed (Table 2). ${ }^{12-19}$ The most common dosage of tigecycline used in these cases was a 100-mg loading dose followed by $50 \mathrm{mg}$ twice daily. For only 4 of the cases was tigecycline susceptibility reported. ${ }^{12-15}$ A negative clinical and/or microbiological outcome occurred in 4 patients. ${ }^{12-14,19}$ One death was reported, but the cause of death was unrelated to the infection. ${ }^{13}$ No patient-specific negative outcome information was provided in the case series. ${ }^{19}$ In the case reported by Drekonja and Johnson, ${ }^{14}$ the patient underwent only 2 weeks of therapy for prostatitis, and the results of repeat urine culture were positive for an ESBLproducing $E$. coli. This outcome may have been the result of suboptimal therapy for chronic prostatitis, as the usual duration of treatment for chronic bacterial prostatitis is $4-6$ weeks. In the case reported by Reid and others ${ }^{12}$, hospital-acquired pneumonia developed 20 days after the tigecycline was discontinued, and culture of the sputum yielded $A$. baumannii with a tigecycline MIC of $2 \mu \mathrm{g} / \mathrm{mL}$ (where the MIC for sensitive bacteria would be less than $2 \mu \mathrm{g} / \mathrm{mL}$ ) and Stenotrophomonas maltophilia. At about the same time, the patient started to experience back pain, and spinal osteomyelitis and a paraspinal abscess were discovered. Two isolates of $A$. baumannii (tigecycline MIC $24 \mu \mathrm{g} / \mathrm{mL}$ ) were identified in the fluid drained from the abscess. Urine culture results were also positive for $A$. baumannii (tigecycline MIC $24 \mu \mathrm{g} / \mathrm{mL}$ ). The patient was treated successfully with colistin and ceftazidime.

Some clinicians have used higher doses of tigecycline (200 $\mathrm{mg}$ or $400 \mathrm{mg}$ daily) to achieve higher urinary concentrations, as the drug displays linear pharmacokinetics., ${ }^{7,2,20,21}$ The $400-\mathrm{mg}$ dose has been effective against MDR strains of $K$. pneumoniae and $A$. baumannii with higher MIC values. One author reported no increase in the incidence of nausea and vomiting with higher tigecycline doses..$^{16,20}$

Satlin and others ${ }^{22}$ published a retrospective cohort study of urinary tract infection caused by carbapenem-resistant $K$. pneumoniae and treated with aminoglycosides $(n=41)$, polymyxin $\mathrm{B}(n=25)$, or tigecycline $(n=21)$; a fourth cohort $(n=69)$ received antimicrobial therapy with no activity against gram-negative organisms. The primary outcome was microbiological clearance, defined as follow-up urine culture from which carbapenem-resistant $K$. pneumoniae was not isolated. There were no statistically significant differences between cohorts for any baseline or treatment-associated variables. All of the tigecycline-treated patients received an initial dose of $100 \mathrm{mg}$ IV followed by $50 \mathrm{mg}$ twice daily. The microbiologic clearance rate was $88 \%$ in the aminoglycoside cohort, $64 \%$ in the polymyxin B cohort, $43 \%$ in the tigecycline cohort, and $36 \%$ for patients receiving antibiotics with no gram-negative coverage. As in the case reported here, tigecycline was unable to clear the ESBL-producing $E$. coli from the urine.

The literature search revealed only 2 cases of urinary tract infection manifesting as prostatitis. In the case reported by Geerlings and others, ${ }^{18}$ prostatitis was suspected as the cause of recurrent urinary tract infection, and the patient received 6 weeks of tigecycline therapy (dose not reported), with no recurrence 5 months after therapy. No supplemental information was provided. Drekonja and Johnson ${ }^{14}$ also reported a case of recurrent urinary tract infection secondary to prostatitis. 
Table 2. Summary of Case Reports of Tigecycline Therapy in Cases of Urinary Tract Infection

\begin{tabular}{|c|c|c|c|c|c|c|c|c|}
\hline \multirow[b]{2}{*}{ Reference } & \multirow[b]{2}{*}{ Sex } & \multirow[b]{2}{*}{$\begin{array}{c}\text { Age } \\
\text { (years) }\end{array}$} & \multirow[b]{2}{*}{ Organism(s) } & \multirow[b]{2}{*}{$\begin{array}{l}\text { Dose of } \\
\text { Tigecycline }\end{array}$} & \multirow[b]{2}{*}{$\begin{array}{l}\text { Duration of } \\
\text { Therapy (days) }\end{array}$} & \multicolumn{2}{|c|}{ Outcome } & \multirow[b]{2}{*}{$\begin{array}{l}\text { Length of } \\
\text { Hospital Stay }\end{array}$} \\
\hline & & & & & & Clinical* & Microbiologicalt & \\
\hline Reid et al. ${ }^{12}$ & $\mathrm{~F}$ & 53 & $\begin{array}{c}\text { Acinetobacter } \\
\text { baumannii }\end{array}$ & $\begin{array}{l}\text { 100-mg load, } \\
50 \mathrm{mg} \text { q12h }\end{array}$ & 14 & Negative & Negative & 3 months \\
\hline \multirow[t]{2}{*}{ Anthony et al..$^{13}$} & $F$ & 54 & $\begin{array}{c}\text { Acinetobacter } \\
\text { baumannii }\end{array}$ & $\begin{array}{l}100-\mathrm{mg} \text { load, } \\
50 \mathrm{mg} \text { q12h }\end{array}$ & 17 & Positive & Positive & 26 days \\
\hline & M & 64 & $\begin{array}{c}\text { Klebsiella } \\
\text { pneumoniae }\end{array}$ & $\begin{array}{l}100-\mathrm{mg} \text { load, } \\
50 \mathrm{mg} \mathrm{q} 12 \mathrm{~h}\end{array}$ & 11 & Negative & Positive & 15 days \\
\hline $\begin{array}{l}\text { Drekonja and } \\
\text { Johnson }^{14}\end{array}$ & $\mathrm{M}$ & 63 & $\begin{array}{l}\text { ESBL-producing } \\
\text { Escherichia coli }\end{array}$ & $\begin{array}{l}\text { 100-mg load, } \\
50 \text { mg q12h }\end{array}$ & 14 & Positive & Negative & NR \\
\hline \multirow[t]{3}{*}{$\begin{array}{l}\text { Gallagher and } \\
\text { Rouse }^{15}\end{array}$} & NR & 63 & $\begin{array}{c}\text { Acinetobacter } \\
\text { baumannii }\end{array}$ & $\begin{array}{l}100-\mathrm{mg} \text { load, } \\
50 \text { mg q12h }\end{array}$ & 4 & Positive & Positive & NR \\
\hline & NR & 49 & $\begin{array}{c}\text { Acinetobacter } \\
\text { baumannii }\end{array}$ & $\begin{array}{l}100-\mathrm{mg} \text { load, } \\
50 \mathrm{mg} \mathrm{q} 12 \mathrm{~h}\end{array}$ & 13 & Positive & Positive & NR \\
\hline & NR & 63 & $\begin{array}{c}\text { Acinetobacter } \\
\text { baumannii }\end{array}$ & $\begin{array}{l}100-\mathrm{mg} \text { load, } \\
50 \mathrm{mg} \text { q12h }\end{array}$ & 12 & Positive & Positive & NR \\
\hline Cunha $^{16}$ & $\mathrm{M}$ & "Elderly" & $\begin{array}{c}\text { Klebsiella } \\
\text { pneumoniae, } \\
\text { Enterobacter } \\
\text { aerogenes }\end{array}$ & 200 mg daily & 14 & Positive & Positive & NR \\
\hline Krueger et al. ${ }^{17}$ & $\mathrm{~F}$ & 25 & $\begin{array}{l}\text { ESBL-producing } \\
\text { Escherichia coli }\end{array}$ & NR & 13 & Positive & NR & 38 days \\
\hline \multirow[t]{2}{*}{ Geerlings et al. ${ }^{18}$} & $\mathrm{M}$ & 44 & $\begin{array}{l}\text { ESBL-producing } \\
\text { Escherichia coli }\end{array}$ & NR & 42 & Positive & NR & NR \\
\hline & $\mathrm{F}$ & 66 & $\begin{array}{l}\text { ESBL-producing } \\
\text { Escherichia coli }\end{array}$ & NR & 42 & Positive & NR & NR \\
\hline Kuo et al. ${ }^{19}$ ף & $\mathrm{M}$ & 76 & $\begin{array}{c}\text { Acinetobacter } \\
\text { baumannii }\end{array}$ & $\begin{array}{l}100-\mathrm{mg} \text { load, } \\
50 \mathrm{mg} \text { q12h§ }\end{array}$ & 12 & Negative & Negative & NR \\
\hline
\end{tabular}

ESBL = extended-spectrum B-lactamase-producing, NR = not reported.

${ }^{*}$ Clincial cure defined as resolution of signs and symptoms of infection.

†Microbiological eradication defined as a negative result on repeat culturing.

¥Patient also received colistin concurrently.

§Patient also received imipenem-sulbactam concurrently.

ПThese authors reported a case series of patients treated with tigecycline, but only one of the patients had a urinary tract infection.

After completing a 2-week course of tigecycline $(100 \mathrm{mg}$ followed by $50 \mathrm{mg}$ twice daily), the patient was asymptomatic, and his prostate was smaller and nontender. Urinalysis revealed no pyuria, the results of urine culture were negative, and the prostate-specific antigen level had decreased from $13.36 \mu \mathrm{g} / \mathrm{L}$ to $6.23 \mu \mathrm{g} / \mathrm{L}$ (normal range $0-4.5 \mu \mathrm{g} / \mathrm{L}$ ). One month after completing therapy, repeat urine culture yielded an ESBLproducing E. coli. However, the patient remained asymptomatic over the next 5 months and did not receive any antimicrobials. In the case presented here, the patient also had persistent bacteriuria following treatment with tigecycline.

Clinicians have few antibiotic options for the treatment of infections with MDR gram-negative organisms. Furthermore, no new antibiotics with activity against MDR gram-negative organisms are expected to be released within the next 5 years. ${ }^{23}$ In the case presented here, the patient initially received piperacillin-tazobactam. The clinical evidence regarding the usefulness of ß-lactam/ß-lactamase inhibitor combinations for the treatment of ESBL infections is limited. ${ }^{4,5}$
Piperacillin-tazobactam achieves high concentrations in the urinary tract and has been used successfully in the treatment of ESBL-producing organisms. ${ }^{4,5}$ However, many failures have been described, and resistance may develop during therapy. ${ }^{24}$ Carbapenems are considered the drug of choice against serious infections due to ESBL-producing bacteria. ${ }^{4,5}$ Unfortunately, the patient described here experienced a leukocytoclastic vasculitic rash secondary to carbapenem therapy, which precluded further ß-lactam therapies (such as temocillin or cefoxitin-cefotetan). ${ }^{25,26}$

The propensity of ESBL-producing organisms to be resistant to many classes of antibiotics greatly limits the choice of treatments. The genes encoding for ESBL enzymes are located on large plasmids that can (and usually do) harbour genes for resistance to fluoroquinolones, aminoglycosides, and cotrimoxazole. ${ }^{4.5}$ In the case presented here, the ESBLproducing $E$. coli in urine and blood was sensitive to sulfamethoxazole-trimethoprim and gentamicin. The potential for emergence of resistance during treatment with 
sulfamethoxazole-trimethoprim often precludes its use as empiric therapy. ${ }^{5}$ In addition, the trimethoprim component tends to cause hyperkalemia in individuals with prior renal disease, which further limits its use. ${ }^{27}$ Nephrotoxicity has been reported with aminoglycosides (in up to $50 \%$ of patients) and colistin (in up to $40 \%$ of patients), and the patient described here had chronic renal failure. Therefore, neither of these therapies was a suitable option. ${ }^{23,28}$

Most antibiotics are either weak acids or weak bases that ionize in biological fluids, which inhibits their ability to cross the prostatic epithelium. Penetration of a drug into the prostate will be enhanced by a high concentration gradient, high lipid solubility, low degree of ionization, high dissociation (i.e., pKa allowing diffusion of the un-ionized component into the prostate), low protein binding, and small molecular size. ${ }^{910}$ Surprisingly few antibiotics achieve clinically significant prostatic penetration; these include fluoroquinolones, tetracycline, and sulfamethoxazole-trimethoprim. Tigecycline is a small molecule (molecular weight 586 daltons) that is highly ionic and freely soluble throughout the entire $\mathrm{pH}$ range of 1 to 14 . The drug is approximately $71 \%-89 \%$ bound to plasma proteins. ${ }^{6.7}$ It has an n-octanol-water partition coefficient of 1.338 at $\mathrm{pH} 8$, where a value less than 10 is considered relatively hydrophilic (J. Drummond, Medical Information, Pfizer Canada; personal communication, November 18, 2011). Its physicochemical characteristics suggest that tigecycline may not have good penetration into prostatic tissue; however, there is a lack of clinical evidence to show decreased efficacy in the treatment of prostatitis.

Fosfomycin and nitrofurantoin are 2 other antibiotics that could be used to treat an ESBL-producing organism causing uncomplicated cystitis. ${ }^{4,5,29}$ However, because the patient described here had pyelonephritis and prostatitis, these agents were not suitable options. Nitrofurantoin does not achieve therapeutic concentrations in the prostate. 'Fosfomycin has been shown to produce outcomes similar to those of carbapenems in complicated lower urinary tract infections caused by ESBL-producing organisms. ${ }^{30}$ However, this drug was discontinued by Triton Pharma Inc (Montréal, Quebec) in July 2011 and is available only through Health Canada's Special Access Programme. It is not currently licensed for the treatment of complicated upper urinary tract infections, and the optimal dose and duration of therapy have not been evaluated in clinical trials. ${ }^{31}$ There is also a lack of information about the use of fosfomycin in the treatment of prostatitis; however, it has been suggested that fosfomycin has good penetration into the prostate, achieving levels approximately $30 \%$ of those in the serum. ${ }^{32,33}$

Overall, tigecycline therapy was deemed the best option for treatment of pyelonephritis and prostatitis caused by ESBLproducing E. coli in this patient with chronic renal failure, baseline hyperkalemia, and documented B-lactam intolerance.

\section{CONCLUSIONS}

Tigecycline undergoes minimal urinary excretion, but the literature suggests that the drug is a viable second-line option to treat urinary tract infections caused by MDR organisms. Treatment of urinary tract infections with tigecycline $100 \mathrm{mg}$ followed by $50 \mathrm{mg}$ twice daily appears to be associated with positive clinical outcomes; however, bacteriuria may persist in about $50 \%$ of patients after completion of treatment. In the case presented here, a 6-week course of tigecycline therapy was well tolerated, with no reports of nausea or increase in liver enzymes; however, this therapy did not eradicate the organism. To the authors' knowledge, only 3 cases describing tigecycline therapy in the treatment of prostatitis have been reported. Large randomized, double-blind trials are needed to determine the role of tigecycline in the treatment of complicated urinary tract infections, including pyelonephritis and prostatitis.

\section{References}

1. Cai Y, Wang R, Liang B, Bai N, Liu Y. Systematic review and metaanalysis of the effectiveness and safety of tigecycline for the treatment of infectious disease. Antimicrob Agents Chemother 2011;55(3):1162-1172.

2. FDA drug safety communication: increased risk of death with Tygacil (tigecycline) compared to other antibiotics used to treat similar infections. Silver Spring (MD): US Food and Drug Administration; 2010 Sep 1 [cited 2011 Oct 24]. Available from: www.fda.gov/Drugs/DrugSafety/ ucm 224370.htm

3. Hsueh PR, Hoban DJ, Carmeli Y, Chen SY, Desikan S, Alejandria M, et al. Consensus review of the epidemiology and appropriate antimicrobial therapy of complicated urinary tract infections in Asia-Pacific region. J Infect 2011;63(2):114-123.

4. Pitout JDD. Infections with extended-spectrum-ß-lactamase-producing Enterobacteriaceae. Changing epidemiology and drug treatment choices. Drugs 2010;70(3):313-333.

5. Kanj SS, Kanafani ZA. Current concepts in antimicrobial therapy against resistant gram-negative organisms: extended spectrum B-lactamaseproducing Enterobacteriaceae, carbapenem-resistant Enterobacteriaceae and multidrug-resistant Pseudomonas aeruginosa. Mayo Clin Proc 2011; 86(3):250-259.

6. Barbour A, Schmidt S, Ma B, Schiefelbein L, Rand KH, Burkhardt O, et al. Clinical pharmacokinetics and pharmacodynamics of tigecycline. Clin Pharmacokinet 2009; 48(9):575-584.

7. Tygacil product monograph. Kirkland (QC): Pfizer Canada Inc; 2011 Jun 10.

8. Falagas ME, Karageorgopoulos DE, Dimopoulos G. Clinical significance of the pharmacokinetic and pharmacodynamics characteristics of tigecycline. Curr Drug Metab 2009;10(1):13-21.

9. Charalabopoulos K, Karachalios G, Baltogiannis D, Charalabopoulos A, Giannakopoulos X, Sofikitis N. Penetration of antimicrobial agents into the prostate. Chemotherapy 2003;49(6):269-279.

10. Lipsky BA, Byren I, Hoey CT. Treatment of bacterial prostatitis. Clin Infect Dis 2010;50(12):1641-1652.

11. Vwergoulidou M, Adam T, Gaki B, Thiel E, Uharek L, Schwartz S. Use of tigecycline in patients (pts) with neutropenic hematological diseases or hematopoietic stem cell transplantation (HSCT) [abstract]. Onkologie 2010;33(6):70.

12. Reid GE, Grim SA, Aldeza CA, Janda WM, Clark NM. Rapid development of Acinetobacter baumannii resistance to tigecycline. Pharmacotherapy 2007;27(8):1198-1201.

13. Anthony KB, Fishman NO, Linki DR, Gasink LB, Edelstein PH, Lautenbach E. Clinical and microbiological outcomes of serious infections with multidrug-resistant gram-negative organisms treated with tigecycline. Clin Infect Dis 2008;46(4):567-570.

14. Drekonja DM, Johnson JR. Tigecycline treatment for urinary tract infections: case report and literature review. J Chemother 2011;23(3):168-170.

15. Gallagher JC, Rouse HM. Tigecycline for the treatment of Acinetobacter infections: a case series. Ann Pharmacother 2008;42(9):1188-1194.

16. Cunha BA, McDermott B, Nausheen S. Single daily high-dose tigecycline therapy of a multi-drug resistant (MDR) Klebsiella pneumoniae and Enterobacter aerogenes nosocomial urinary tract infection. J Chemother 2007;19(5):753-754. 
17. Krueger WA, Kempf VAJ, Peiffer M, Nagele U, Unertl KE, Schroeder TH. Treatment with tigecycline of recurrent urosepsis caused by extendedspectrum-B-lactamase-producing Escherichia coli. J Clin Microbiol 2008;46(2):817-820

18. Geerlings SE, van Donselaar-van der Pant KAMI, Keur I. Successful treatment with tigecycline of two patients with complicated urinary tract infections caused by extended-spectrum-ß-lactamase-producing Escherichia coli. J Antimicrob Chemother 2010;65(9):2048-2049.

19. Kuo SC, Wang FD, Fung CP, Chen LY, Chiang MC, Hsu SF, et al. Clinical experience with tigecycline as treatment for serious infections in elderly and critically ill patients. J Microbiol Immunol Infect 2011;44(1):45-51.

20. Cunha BA. Pharmacokinetic considerations regarding tigecycline for multidrug-resistant (MDR) Klebsiella pneumoniae or MDR Acinetobacter baumannii urosepsis. J Clin Microbiol 2009;47(5):1613.

21. Nix DE, Matthias KR. Should tigecycline be considered for urinary tract infections? A pharmacokinetic re-evaluation. I Antimicrob Chemother 2010;65(6):1311-1312.

22. Satlin MJ, Kubin CJ, Blumenthal JS, Cohen AB, Furuya EY, Wilson SL, et al. Comparative effectiveness of aminoglycosides, polymyxin $\mathrm{B}$, and tigecycline for the clearance of carbapenem-resistant Klebsiella pneumoniae from the urine. Antimcrob Agents Chemother 2011;55(12):5893-5899.

23. Lim LM, Ly N, Andersen D, Yang JC, Macander L, Jarkowski A, et al. Resurgence of colistin: a review of resistance, toxicity, pharmacodynamics, and dosing. Pharmacotherapy 2010;30(12):1279-1291.

24. Munoz-Price LS, Jacoby GA. Extended-spectrum beta-lactamases. In: UpToDate online [Internet database]. Version 19.2. Waltham (MA): UpToDate Inc; [updated 2011 Apr 15; cited 2011 Oct 28]. Available from: www.uptodateoneline.com (subscription required to access content).

25. Livermore DM, Hope R, Fagan EJ, Warner M, Woodford N, Pota N. Activity of temocillin against prevalent ESBL and AmpC-producing Enterobacteriaceace from south-east England. J Antimicrob Chemother 2006;57(5):1012-1014

26. D’Azevedo PA, Goncalves ALS, Musskopf MI, Ramos CG, Dias CAG. Laboratory tests in the detection of extended spectrum beta-lactamases production: National Committee for Clinical Laboratory Standards (NCCLS) screening test, the E-test, the double disk confirmatory test, and cefoxitin susceptibility testing. Braz J Infect Dis 2004;8(5):372-377.

27. Greenberg S, Reiser IW, Chou SY, Porush JG. Trimethoprimsulfamethoxazole induces reversible hyperkalemia. Ann Intern Med 1993;119(4):291-295.

28. Gilbert DN, Leggett JE. Aminoglycosides. In: Mandell GL, Bennett JE, Dolin R. Mandell, Douglas, Bennett's principles and practice of infectious diseases. 7 th edition. Philadelphia (PA): Churchill Livingstone Elsevier; 2010 [cited 2011 Oct 28]. Available from www.mdconsult.com (subscription required to access content).

29. Garau J. Other antimicrobials of interest in the era of extended-spectrum B-lactamases: fosfomycin, nitrofurantoin and tigecycline. Clin Microbiol Infect 2008;14 Suppl 1:198-202.
30. Senol S, Tasbakan M, Pullukcu H, Sipahi O, Sipahi H, Yamazhan T. Carbapenem versus fosfomycin tromethanol in the treatment of extendedspectrum beta-lactamase-producing Escherichia coli-related complicated lower urinary tract infections. J Chemother 2010;22(5):355-357.

31. Nicolle LE. Update in adult urinary tract infection. Curr Infect Dis Rep 2011;13(6):552-560.

32. Michalopoulos AS, Livaditis IG, Gougoutas V. The revival of fosfomycin. Int J Infect Dis 2011;15(11):e732-e739.

33. Yoshimoto J, Ochi J. Study of the prostatic tissue levels of antimicrobial agents: concerning fosfomycin sodium. Nishinihon J Urol 1986;48(4) $1423-1428$.

Duane Bates, BScPharm, ACPR, is the Clinical Practice Leader, Department of Pharmacy, Foothills Medical Centre, Alberta Health Services, Calgary, Alberta.

Mike Parkins, MD, MSC, FRCPC, is an Assistant Professor with the Department of Medicine, Division of Infectious Diseases, University of Calgary and Peter Lougheed Centre, Alberta Health Services, Calgary, Alberta.

Robin Hellweg, BSCPharm is a Clinical Pharmacist with the Department of Pharmacy, Peter Lougheed Centre, Alberta Health Services, Calgary, Alberta.

Kimberly Gibson, BScPharm, ACPR, is a Clinical Pharmacist with the Department of Pharmacy, Peter Lougheed Centre, Alberta Health Services, Calgary, Alberta.

Jennifer M Bugar, BSC, MD, FRCPC, is an Assistant Professor and Associate Program Director-Internal Medicine Residency Program with the division of Internal Medicine, Department of Medicine, University of Calgary and Peter Lougheed Centre, Alberta Health Services, Calgary, Alberta.

\section{Address correspondence to:}

Duane Bates

Department of Pharmacy

Foothills Medical Centre

Alberta Health Services

1403 29th Street NW

Calgary AB T2N 2T9

e-mail: duane.bates@albertahealthservices.ca 